\title{
ЖАНРОВО-СТИЛІСТИЧНА ПОЛІФОНІЯ РЕЖИСЕРСЬКОÏ ТВОРЧОСТІ РОМАНА ВІКТЮКА
}

\author{
Тетяна Бойко1a, Ярослав Ланчак ${ }^{2 a}$ \\ ${ }^{1}$ кандидат мистецтвознавства, старший науковий співробітник; \\ e-mail: tetiana.boyko@gmail.com; ORCID: 0000-0001-6941-8868 \\ ${ }^{2}$ магістр; e-mail: lanchak0804@gmail.com; ORCID: 0000-0001-9282-8988

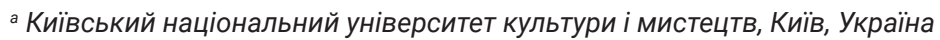

\begin{abstract}
Анотація
Мета дослідження - з'ясувати специфіку сценічного доробку Романа Віктюка, проаналізувати окремі аспекти апробованої пластичної режисури, окреслити жанрово-стилістичні параметри резонансних постановок митця кінця 1970-х - початку 2010-х рр. на прикладі вистав «Татуйована троянда» Т. Вільямса (1982), «Украдене щастя» І. Франка (1982), «Федра» М. Цвєтаєвої (1988), «Священні чудовиська» Ж. Кокто $(1987)$, «Уроки музики» $(1979,1989)$ та «Квартира Коломбіни» (1986) Л. Петрушевської, «Уроки майстра» Д. Паунелла (1990), «Служниці» Ж. Жене (1988), «Лоліта» Е. Олбі (1992), « раптом минулого літа» Т. Вільямса (2016) тощо. Методологія дослідження. Для досягнення поставленої мети було застосовано загальнонаукові методи: аналітичний (для розуміння процесу творчого становлення та формування концептуальних орієнтирів режисера), типологічно-структурний (для вивчення елементів режисерського інструментарію та художніх прийомів митця), феноменологічний (для визначення рис оригінальності й епатажності сценічної практики Романа Віктюка). Наукова новизна цієї статті визначається введенням до вітчизняного наукового обігу фрагментів театральної режисури Романа Віктюка, полягає в окресленні жанровостилістичних особливостей його постановок, розгляді окремих вистав. Висновки. Сценічний доробок Романа Віктюка вирізняється розмаїттям музики та хореографії, вишуканою пластикою напівоголених виконавців, промовистими костюмами та сценами епатажу. Водночас режисерські пошуки націлені на розв'язання складних філософських питань, що демонструють новий погляд на природу людських стосунків, глибинне дослідження та переосмислення літературних творів.

Ключові слова: Роман Віктюк; авторська режисура; жанр; метафоричний театр; поетичний театр; пластична режисура; епатаж
\end{abstract}

\section{Постановка проблеми}

На сучасному етапі творчість видатного російського й українського режисера Романа Віктюка є поживою та стимулом для мистецтвознавчого аналізу. Адже 
його естетські й епатажні постановки останньої чверті XX - початку XXI століття якнайкраще демонструють квінтесенції метафоричного театру та образних пластичних рішень.

Сміливі режисерські рішення Р. Віктюка, що проявилися в поєднанні пластичного та драматичного мистецтва в єдиному сценічному творі, формуванні особливої вишуканої структури та краси рухів, затвердили нову театральну естетику, яка вимагає від глядача глибинних почуттів, емоційності та філософського сприйняття. Режисура Р. Віктюка виразна та неординарна для фахового ока, вона потребує осмислення й теоретичних узагальнень у контексті розуміння театру сучасності.

Попри те, що з 1996 року митець керував Театром Романа Віктюка у Москві, його постать знакова і для української сцени. Адже він народився у Львові, а після закінчення Державного інституту театрального мистецтва в Москві (рос. - ГИТИС) знову повернувся до рідного міста, аби почати успішний творчий злет, який протягом усієї кар'єри режисера (здійснив постановки в Україні, Литві, Латвії, Італії, США, Фінляндії тощо) скеровував його мистецьку траєкторію до естетичного бунтарства та формотворчого поступу. Приміром, його роботи у Львові та Києві були помітними прецедентами в процесі згасання соцреалістичної естетики та пошуку метафоричної образності й сценічного формотворення.

Утім, незважаючи на наявність у вітчизняному науковому полі певної кількості мистецтво- і театрознавчих праць, де висвітлено процес формування режисерських концептів українського театру, практика Р. Віктюка проаналізована лише локальними епізодами вистав на київській сцені.

Відтак актуальність теми зумовлена необхідністю осмислення творчих концептів Р. Віктюка, а також режисерських прийомів і методів їх практичної реалізації в контексті еволюціонування та трансформації театрального мистецтва кінця XX - початку XXI століття.

\section{Аналіз останніх досліджень і публікацій}

Певний спектр аналітичних міркувань щодо творчості Р. Віктюка здебільшого міститься у працях зарубіжних (російських) дослідників. Серед цих праць, приміром, окремі аспекти вистав Театру Романа Віктюка проаналізувала О. Юшкова (2004) у праці «Пластичний театр XX століття в Росії», а особливості інтерпретації п'єси М. Цвєтаєвої «Федра» осмислив О. Смольяков (1998) у дослідженні «Стилізація в російській поетичній драмі початку XX століття: драматургічний цикл».

Важливим джерелом інформації є й спогади про співпрацю з Р. Віктюком відомих діячів культури, акторів і драматургів: О. Іванова (2012) «Субкультура недавнього минулого», Л. Петрушевської (2006) «Маленька дівчинка з "Метрополя"», І. Мірошниченко (2017) тощо.

Доволі оригінальний аналіз таких постановок Р. Віктюка, як «Пробудження весни», «Містерія Еросу і Танатосу» та «Саломея», пропонує відомий психолог Андрій Курпатов (2018) у монографії «Страх. Хтивість. Смерть».

Ознайомлення зі специфікою режисури Р. Віктюка (2003), фрагментами його творчої діяльності, а головне - осмисленням філософії майстра є автобіогра- 
фічні книги «Роман з самим собою», «Небо. Політ перший» (2018), «Небо. Політ другий» (2018) та багаторічна праця А. Мурзич (2008) «Театр Романа Віктюка. З крапки у вічність», в якій зібрано багато інтерв'ю з режисером, здійснено аналіз більшості його легендарних вистав.

Утім, специфіка режисерської діяльності Р. Віктюка наразі не отримала цілісного висвітлення в контексті вітчизняної науки. Здебільшого творчий доробок митця задокументовано на шпальтах української та зарубіжної періодики різних років, аналіз та систематизація яких нині на часі. Серед українських науковців виставу Р. Віктюка «Уроки музики» за Л. Петрушевською (1989) на сцені Київського театру російської драми ім. Лесі Українки висвітлила Марина Гринишина (2017) у науковій праці «Національний академічний театр російської драми ім. Лесі Українки (1926-2014рр.)». Іншу резонансну виставу київської сцени - «Священні чудовиська» (1987) - проаналізувала Анна Липківська (2012, с.793-806) на сторінках видання «Український театр XX ст.: Антологія вистав».

y підсумку зазначимо, що наведений перелік джерел засвідчив наявність саме зарубіжної (російської) наукової літератури, присвяченої творчості режисера Р. Віктюка. Натомість у царині вітчизняної науки бракує досліджень, де було б послідовно висвітлено бодай репрезентативні вистави режисера.

Мета роботи - з'ясувати специфіку сценічного доробку Р. Віктюка, окреслити жанрово-стилістичні параметри резонансних постановок митця, проаналізувати окремі аспекти пластичної режисури (на прикладі вистав «Татуйована троянда» Т. Вільямса (1982), «Украдене щастя» І. Франка (1982), «Федра» М. Цвєтаєвої (1988), «Священні чудовиська» Ж. Кокто (1987), «Уроки музики» $(1979,1989)$ та «Квартира Коломбіни» (1986) Л. Петрушевської, «Уроки майстра» Д. Паунелла (1990), «Служниці» Ж. Жене (1988), «Лоліта» Е. Олбі (1992), «І раптом минулого літа» Т. Вільямса (2016) тощо).

Для досягнення поставленої мети застосовано загальнонаукові методи: аналітичний (для розуміння процесу творчого становлення та формування концептуальних орієнтирів режисера), типологічно-структурний (для вивчення елементів режисерського інструментарію та художніх прийомів митця), феноменологічний (для визначення рис оригінальності й епатажності сценічної практики Р. Віктюка).

\section{Виклад основного матеріалу}

Вступ. Головними ознаками художньо-ідейного поступу театральної практики останньої чверті XX - початку XXI століття стали експерименти, пошуки та мистецькі рефлексії. Ці реалії своєю чергою скерували вектори режисерської творчості до полістилістики, залучення різноманітних технологічних новацій і вплинули на формування авторських, режисерських методів. У театральній царині означеного періоду змінилося розташування сил між авторами - виконавцями - глядачами, звільнивши поле для режисерського висловлювання. На думку дослідниці Олени Романової (2004, с.3), провідні постмодерністські експерименти в театральній практиці засвідчують переоцінку ролі режисера, актора 
Bulletin of Kyiv National University of Culture and Arts

Series in Stage Art

та глядача, оскільки постмодерністська режисура позиціює виставу як відкритий та нецентрований сценічний твір, наслідує принципи імпровізаційності або інсталяції, нерідко звертаючись до зміщування стилю гри; актор дистанціюється від персонажа, створюючи поряд з постановником театральну структуру за допомогою знаків; глядач отримує змістовні елементи, що естетично презентують виставу.

Відтак художня цінність вистав означеного періоду відрізняється ступенем сценічної образності, що впливає на глядача на рівні свідомого та несвідомого таким чином здійснюється прорив глибинного сприйняття сенсу вистави через різноманітні засоби виразності (Литвин, 1993, с. 3).

Отже, авторами та творцями образної структури вистав постають режисери, які реалізують через акторів своєрідний діалог з глядачами, а відтак їх пошуки образності можемо розглядати як пошуки новаторських контактів з глядачами через творче, індивідуальне «обличчя» акторів. У процесі творчої співпраці режисери й актори видобувають з матеріалу п'єс невербальні засоби виразності, спрямовані на образно-асоціативне сприйняття глядача.

Загальновідомо, що процес створення вистави дослідники умовно поділяють на три етапи:

- зародження режисерського задуму, ідеї, що поєднує акторів, сценографа, композитора й інших учасників;

- опанування з боку акторів просторово-часового континууму вистави (дії, середовища, ритму, темпу, пауз, мізансцени, жанру, стилю та ін.);

- доведення композиційного перетворення елементів режисерської виразності (події, дія, ритм, паузи, мізансцена та ін.) до художньої цілісності всіх складових вистави в жанрово-стильовій єдності (Литвин, 1993, с. 4).

Беззаперечним є і те, що специфіка поєднання цих етапів, залежно від багатьох об'єктивних і суб'єктивних чинників, вирізняється яскравою індивідуальністю не тільки в різних режисерів та виставах одного режисера, а й у різних сценічних редакціях одного й того ж драматичного твору.

До об'єктивних чинників належать зовнішні елементи: досвід і майстерність актора, сценографа, композитора, їх творча воля та сумісність з режисерським задумом. До суб'єктивних належать: специфіка фантазії та уяви як основних психологічних механізмів режисерської творчості. Так, взаємозалежність цих чинників призводить до процесу режисерського формотворення, в якому народжуються нові змісти та візії сценічного твору. Відтак на зламі XX-XXI століть апогеєм сценічного формотворення стало утвердження авторської режисури.

Особливості пошукових векторів і режисерський нонконформізм Р. Віктюка. Вивчення й аналіз режисерської практики багатьох митців часом унеможливлює їі затиск у межах будь-якої системи, як-от реалістичної школи або епічного театру тощо. Наприклад, нині можна вільно стверджувати про авторський театр Пітера Брука, Сергія Данченка, Марка Захарова, Юрія Любимова, Еймунтаса Някрошюса та багатьох інших. Серед когорти згаданих тут митців одне з чільних місць належить і Р. Віктюку (1936-2020). Приміром, вітчизняна театрознавиця Анна Липківська із цього приводу наголошує: «Вистави Романа Віктюка рубежу 
Вісник Київського національного університету культури і мистецтв. Серія: Сценічне мистецтво

1980-1990-х рр. спричинили справжній театральний вибух. Ж. Кокто, Ж. Жене, Т. Реттіґан, Д.-Г. Хуан, В. Набоков з його легкої руки "увірвалися" на стагнований було пізньо-радянський кін і постали там з п'янким присмаком “забороненого плоду", у примхливих абрисах графічних мізансцен, вишуканої, підкреслено театралізованої пластики, свінгового акторського голосоведіння» (Липківська, 2012, с.793).

Роман Віктюк відомий як російський та український театральний режисер, народний артист України (2006), народний артист Російської Федерації (2009), художній керівник Театру Романа Віктюка, театральний новатор, у творчому доробку якого понад 200 вистав. Народився митець у Львові, закінчив Державний інститут театрального мистецтва в Москві, навчаючись у провідних майстрів подружжя Василя та Марії Орлових, Анатолія Ефроса та Юрія Завадського.

1956 року молодий режисер дебютував виставою «Все це не так просто» за п'єсою Г. Шмельова (інсценування оповідання «Щоденник» Л. Ісарової) на сцені Львівського театру юного глядача, а незабаром здійснив постановки вистав «Коли зійде місяць» за п'єсою Г. Грегорі (1965), «Сім'я» І. Попова (1967), «Фабрична дівчина» О. Володіна, «Місто без кохання» Л. Устінова та «Дон Жуан» Ж.-Б. Мольєра.

1968 року Р. Віктюка було запрошено на посаду головного режисера Калінінського театру юного глядача - протягом року він здійснив постановки вистав «Мені хочеться тебе сьогодні бачити» за однойменною авторською п'єсою, «Чарівна ялинка» В. Ткаченко, «Ми, джаз та привиди» Е. Нізюрського, «На одне кохання менше» А. Кузнецова та «Підступність і кохання» Ф. Шиллера, паралельно займаючись режисурою фільмів-вистав.

Саме через новаторську інтерпретацію класичного твору Ф. Шиллера, яку партійне керівництво класифікувало як «інтелектуальну диверсію», у пресі з'явилися негативні критичні статті, а Р. Віктюка було звільнено, навіть незважаючи на позитивну оцінку Марчелло Мастроянні, який був вражений європейським рівнем театральної постановки. Провідний італійський актор особисто був присутній на прем'єрі вистави, оскільки в Калінінській області тривала робота над фільмом «Соняшники».

Протягом 1970-1974 років Р. Віктюк працював головним режисером Російського драматичного театру у Вільнюсі. Завдяки приятельським стосункам з першим секретарем обкому мав можливість обирати п'єси для постановки, що були заборонені в СРСР. Наприклад, він здійснив першу в радянському театральному просторі постановку багатоактної п'єси О. Вампілова «Минулого літа в Чулимську». Відомий драматург, з яким Р. Віктюк товаришував, закінчив роботу над твором ще в 1971 році. Утім, проходження цензури умисно затягували, посилаючись на «ідейну недолугість змісту художньо сирої п'єси» (Николаев, 2014, с.10), уперше її опубліковано лише після загибелі драматурга, влітку 1972 року. За сюжетом у Шаманова (В. Єфремов), який опинився в містечку Чулимську після звільнення з посади міського слідчого за гіпертрофоване відчуття справедливості (він добивався справедливого суду над сином чиновника), закохується молода дівчина Валентина (О. Демичева). Герой також відчуває, що вона йому не байдужа, проте досить сухо це демонструє. Любовний конфлікт посилюється 
діями сина буфетниці Павла (Е. Мурашов), який домагається Валентини, бухгалтера Мечоткіна (Л. Владимиров), який сватається до неї, отримавши згоду батька, та Кашкіної (Т. Майорова), яка прагне привернути увагу Шаманова. Сценічна версія Р. Віктюка без цензури мала назву «Зустрічі та прощання».

Серед інших режисерських робіт Р. Віктюка на сцені Литовського Російського драматичного театру назвемо «Чорну комедію» британського драматурга П. Шеффера, «Валентин і Валентина» М. Рощина (1971); «Принцеса і лісоруб» Г. Волчек та М. Мікаелян, «Кохання - книга золота» О. Толстого, «Справа передається до суду» А. Чхаїдзе (1972); «З коханими не розлучайтесь» О. Володіна, «Продавець дощу» Р. Неша (1973), «Схожий на лева» Р. Ібрагімбекова, «Марія Стюарт» Ю. Словацького та ін.

У другій половині 1970-1980-хрр. професійна діяльність режисера вирізняється надзвичайно різноманітною географією: з 1975 року він почав здійснювати постановки вистав у московських театрах, зокрема в Театрі Моссовета («Вечірнє світло», 1975 р., «Царське полювання» за п'єсою Л. Зоріна, 1977 р.), Московському художньому театрі («Чоловік та жінка знімуть кімнату», 1977 р., «Татуйована троянда, 1982 р.), Студентському театрі МГУ («Чинзано» та «Уроки музики» Л. Петрушевської, 1979 р.; «Качине полювання» О. Вампілова, 1980 р. та ін.).

Серед згаданих творів знаковою у творчості Р. Віктюка стала п'єса «Уроки музики", адже митець захопився стилістикою драматургії Л. Петрушевської - протягом наступних десяти років тричі повертався до неї, здійснивши постановки на сценах Академічного театру ім. Максима Горького (Горький, 1987), Литовського Російського драматичного театру (Вільнюс, 1988), Київського академічного театру російської драми ім. Лесі Українки (Київ, 1989), презентуючи глядачу кожного разу нову версію.

Драматургія Людмили Петрушевської викликала жваві критичні дискусії в художньо-мистецькому та науковому середовищі після появи перших вистав за її п'єсами - протягом 1970-1980-х рр. вони були надзвичайно популярними серед режисерів як академічних театрів, так і театрів-студій.

Дослідниця Наталя Каблукова $(2003$, с.3) стверджує, що драматургія Л. Петрушевської - це комплекс різноманітних уявлень про світ, у центрі якого - людина в дисгармонійному її втіленні. Адже в драматичних творах Л. Петрушевської представлено маргінальний тип людини, яка перебуває в середині багатьох обставин і конфліктів, викинута на узбіччя життя. Створюючи драми про неможливість створення власного світу та досягнення гармонії в родині, у колі друзів, вона досліджує існування сучасної пересічної людини, яка в очах оточення втратила сенс життя.

Причиною дисгармонії є реальні обставини, побутова невлаштованість, а головне - втрата сенсу життя. Дослідники визначають прихований конфлікт у п'єсах Л. Петрушевської як конфлікт самотньої свідомості, що прагне знайти сенс існування та водночас відмовляється від цього, а тому герої діють хаотично, непослідовно або не діють взагалі.

Драматична дія в п'єсах авторки втрачає здатність перетворення висхідної ситуації - вона не стає основою для дії, а у вчинках героїв відсутні і логіка, 
Вісник Київського національного університету культури і мистецтв. Серія: Сценічне мистецтво

і причинно-наслідкові зв'язки, або ж вони засновані на хаотичній свідомості індивіда. Як наслідок, у п'єсах відсутня напруга розвитку дії та динамічність - дія розпадається на безліч різноманітних колізій, а відповідно до поліконфліктності драми в розвитку дії неабияку роль відіграє випадковість. Н. Каблукова визначає цю випадковість як прояв нелогічної поведінки героя та багатоманіття життєвого потоку, від якого людина відчужена. На думку дослідниці, конфлікт у драмах авторки представлено на кількох рівнях: побутовому, що пов'язано з соціальними проблемами; психологічному, що пов'язаний з протиріччям внутрішнього світу та вчинками персонажів; буттєвому, що пов'язаний з утіленням драматичного стану світу на рівні авторської свідомості (Каблукова, 2003, с.3).

Перша постановка Р. Віктюка п'єси «Уроки музики» відбулася 1979 року першопрочитання цього драматичного твору, написаного Л. Петрушевською в 1973 році, а надрукованого лише у 1983 році. Постановка зі студійцями Театру МГУ (Г. Стаханова - Галя, Н. Степанов - Іванов), професійних акторів серед них майже не було, окрім В. Тализіної (Таїсія), одразу викликала надзвичайний резонанс серед театралів. Відповідно до режисерської концепції глядацькі місця було встановлено безпосередньо на сцені клубу Московського державного університету в обмеженій кількості, а зал на чотириста місць лишався порожнім.

Тогочасні критики порівнювали виставу за силою впливу з «ударом скальпеля по живій тканині», коли зарадити може лише операційне втручання: «сміх від нісенітниці, міщанської тарабарщини життя співгромадян став кісткою у горлі». Фінал перевертав душу: сім'я Козлових дивилася телевізор, що з бадьорим незнанням бубонів наступні новини або транслював щось, що належало «офіційному» мистецтву тієї доби, а ведуча безпристрасно читала авторські ремарки: «Над затемненою сценою висвітлюються гойдалки, на яких повільно та сумно гойдається Ніна з дитиною на руках... Надя повільно і сумно підноситься на тих самих гойдалках, що і Ніна» (Агишева, 1988, с.60).

Після шостого показу виставу, прем'єра якої відбулася 19 лютого 1979 року та ознаменувала початок «нової хвилі» в драматургії і театрі, заборонив ректор Московського університету, проте за сприяння Олега Єфремова трупа отримала дозвіл на відновлення показу «Уроків музики» на сцені Будинку культури «Москворіччя». Остаточно виставу закрили лише влітку 1980 року - нетерпимість чиновників Міністерства культури пояснювалася активізацією боротьби з негативними явищами радянського суспільства напередодні проведення Олімпійських ігор у Москві.

У 1989 році Р. Віктюк шокував новою інтерпретацією «Уроків музики» вже київську публіку, здійснюючи постановку, навмисно сповнену «граничного ступеня душевного дискомфорту» (Спиридонова, 1989), яку рецензенти порівняли вже не зі скальпелем хірурга, а з «виваженими і акуратними маніпуляціями патологоанатома, який прагне лише встановлення точного та остаточного діагнозу» (Верховець, 1989), на сцені Київського академічного театру російської драми ім. Лесі Українки.

Музичний супровід, який використав Р. Віктюк, відповідав назві вистави в найвужчому розумінні та концепції постановки, у більш широкому - мелодійне ви- 
конання твору П. Чайковського постійно переривалося голосом чоловіка, який відбивав, ніби під час уроку гри на фортепіано, такт (Гринишина, 2017, с.251).

Сценографія Володимира Боєра відтворювала середовище, в якому речі були ніби своєрідною пластичною метафорою психологічного світу героїв - «безладдя, хаос, який бачимо на сцені, наче модель внутрішнього світу персонажів, де порушена гармонія» (Спиридонова, 1989), відповідаючи режисерському задуму: на стінах було натягнуто папір, що створювало ілюзію екранів; підлога була вкрита пожмаканими папірцями; стояли ліжка, виблискуючи залізними спинками, кульгаві стільці й убогі столи; уособленням єдиного вікна у світ був блакитний екран телевізора вглибині сцени (Гринишина, 2017, с.251).

Лаконізм вираження, динаміку й емоційну структуру вистави режисер досягнув завдяки максимальній природності зовнішніх засобів виразності (слів, жестів, інтонацій, реакцій) виконавського складу, зокрема Н. Шаралапової (Граня), О. Ісаєва (Іванов), Л. Погорєлової (Ніна), О. Сумської (Надія), А. Роговцевої (Таїсія), Є. Паперного (Козлов-старший), В. Задніпровського (Ніколай).

Дослідниця Марина Гринишина $(2017$, с.252) характеризує цю роботу як найважчу, найбезнадійнішу та найбезпросвітнішу виставу з усіх коли-небудь поставлених на сцені Київського академічного театру російської драми.

Варто зазначити, що за кілька років до цього, у 1987 році, Р. Віктюк презентував на київській сцені виставу «Священні чудовиська» за Ж. Кокто, акцентуючи на темі театру, перетворивши виставу з витонченої мелодрами, запропонованої драматургом, на містерію про театр. Головна героїня - велика актриса Естер (А. Роговцева) за жодних обставин не зраджує своєму мистецтву, не вдається до дріб'язкових з'ясувань стосунків, і саме це дає змогу їй у фіналі привести до щасливого завершення життєві колізії.

Бачення режисера розкривала і сценографія Світлани Ставцевої, яка була в стилі модерн - театральному за природою та водночас утопічному в прагненні втілити у статичності образотворчого мистецтва мінливу морську хвилю або невловимий вигин квіткової пелюстки.

Ця подія визнана дослідниками як помітне явище українського театру (Гринишина, 2017, с.264), оскільки постановка радикально вирізнялася не тільки характером літературного першоджерела, а й унікальною, небаченою донині режисерською стилістикою. Слушною є думка Анни Липківської: «Режисер - нібито нізвідки - явив на кону інший театр, разюче несхожий на офіційний. Певною мірою - зірвав греблю для театру пошукового, студійного, відверто альтернативного, чия потужна хвиля накотилася трохи пізніше» $(2012$, с.793). Відтак саме у вирі формотворчих зрушень українського театру відбулися інші постановки Р. Віктюка на київській сцені - «Дама без камелій» Т. Реттіґана (1992) та «Бульвар Сан-Сет» за мотивами фільму Б. Вайлдера (1997).

Пошуковим підходом до режисури вирізнялися й постановки Р. Віктюка на сцені Московського художнього театру ім. Максима Горького, як-от «Татуйована троянда» за п'єсою Т. Вільямса в перекладі Л. Додіна (1982). На той час уже досить популярного в театральній Москві, завдяки епатажним «Урокам музики» та неординарній, незвичній, сміливій і вільній постановці «Чоловік і дружина зні- 
Вісник Київського національного університету культури і мистецтв. Серія: Сценічне мистецтво

муть кімнату» М. Рощина (1976), що кардинально відрізнялася від традиційного стилю MXАТу, режисера до співпраці запросила Ірина Мірошниченко, яка була не тільки виконавицею головної ролі, а й ініціаторкою вистави.

Експериментальна вистава, прем'єра якої відбулася 30 січня 1982 р. на Малій сцені MXATy (сценографія С. Бахріна), ще до початку дивувала глядачів, оскільки починалася, коли вони заходили до залу. Відповідно до задуму режисера головні герої, вдягнуті у святковий одяг (оскільки в них ніби весілля), зустрічали гостей (глядачів), розсаджували чоловіків і жінок на протилежних сторонах залу. Зі спогадів І. Мірошниченко (2017) дізнаємося, що це виправдовувалося специфічною побудовою вистави: «посередині - дорога, протягом всієї дії, а з боків огорожа, і за нею з одного боку крісла, й з іншого боку крісла. Тобто абсолютне проникнення в реальність та справжність того, що відбувається». Поділ на чоловіків і жінок також був продуманий режисером навмисно, щоб долучити глядачів до вистави - після монологу головної героїні пари, які приходили до театру разом, зрозуміло, обурювалися тим, що їх несподівано розділили, на собі відчували весь біль, протест та емоційний стан Серафіни Делла Роза, яка роками живе коханням до свого покійного чоловіка Розаріо, затулившись від світу у своєму безперервному переживанні трагедії.

Ірина Мірошниченко (2017), аналізуючи специфіку режисерської методи Р. Віктюка стверджує, що він не розбирає роль, а вимагає від актора лише чистих пристрастей, проте згодом пропонує їх осмислити. Така метода сприяє переходу до наступного етапу, коли завдяки унікальним особливостям людської пам'яті «в'язанка відчуттів, котрі він вимагав на репетиції, виходить миттєво назовні».

Наступна вистава на кону МХАТівського філіалу визнана критиками еротичною сенсацією 1982 року. Цією виставою, сповненою українського колориту завдяки використанню національного вбрання, західноукраїнських пісень і танців, стала п'єса І. Франка «Украдене щастя». Використовуючи лише голос актриси Ірини Мірошниченко, Р. Віктюку вдалося досягти надзвичайного та настільки потрібного йому ефекту - показати справжню тваринну, природну, брудну та хворобливу, проте надзвичайно сильну пристрасть між Анною (І. Мірошниченко) та Михайлом Гурманом (Б. Щербаков), щоб розкрити головну ідею однієї з найвідоміших класичних п'єс української драматургії відповідно до власного бачення на чужій біді власного щастя не збудувати.

Однією з наступних резонансних вистав Р. Віктюка вже на сцені театру «Сучасник» стала «Квартира Коломбіни» за п'єсами Л. Петрушевської «Кохання», «Сходи», «Анданте» та «Квартира Коломбіни» (1986) з Авангардом Леонтьєвим та Лією Ахеджаковою в головних ролях.

Жанр вистави визначено як комедію-гротеск - настрій своєрідного світу французького водевілю з перших же хвилин формував візуальний образ постановки - «звалений на невеликому дощатому помості, що підноситься над сценою, театрально організований хаос із речей, котрі означують кімнату молодого подружжя в п'єсі “Кохання" [...], посилювала підкреслено шаржована манера гри акторів» (Агишева, 1988, с.59). Апофеозом блюзнірства була фінальна п'єсаодноактівка «Квартира Коломбіни», в якій А. Леонтьєв у ролі П'єро роздягався, обливався водою та з'їдав гіперболізовано довгі макарони. 
За словами критиків, Р. Віктюк пройшов шлях від виявлення трагічної суті напівфантастичних подій, які описувала Л. Петрушевська, до їх театралізаціїта карнавалізації - у цьому проявилася не тільки логіка творчого розвитку режисера, а й логіка розвитку суспільних настроїв (Агишева, 1988, с.59).

Як пише Л. Петрушевська (2006), «режисер презентував світу абсолютно новий продукт. Мої необразливі п'єси стали якимись злегка непристойними [...] це вже починався новий, перетворений Віктюк». Першим актором, якого режисер перевдягнув у жіноче вбрання - рожеву сукню та перуку, став Авангард Леонтьєв. I тут важливо зазначити, що саме вистава «Квартира Коломбіни» поклала початок багатьом експериментам Р. Віктюка, пов'язаним не тільки з переодяганням героїв у строї протилежної статі, а й з тенденцією, коли чоловіки виконують жіночі ролі, а жінки - чоловічі. Цей прийом став ознакою режисерського формотворення Р. Віктюка, а найбільш резонансною виставою - «Служниці» за п'єсою Ж. Жене на кону театру «Сатирикон» 1988 року.

Успіх цієї постановки дав змогу говорити про режисуру Р. Віктюка як про перемогу театральності над буденністю. У цьому творі, відповідно до побажань постановника, були залучені виключно чоловіки. Завдяки розробці особливої акторської пластики Валентина Гнеушева, хореографії Алли Сігалової, підбору музики Асафа Фараджева, костюмам Алли Коженкової, гриму Льва Новикова у поєднанні з акторською грою Костянтина Райкіна (Соланж), Миколи Добриніна (Клер), Олександра Зуєва (Мадам) і Сергія Зарубіна (Месьє) режисерові вдалося створити непересічну виставу та заявити про можливість нового театрального формотворення. Цей спектакль був показаний у багатьох країнах й отримав захоплені відгуки світової преси.

За сюжетом, сестри-служниці Клер і Соланж Лемерсьє, які працюють у будинку Мадам, таємно доносять в поліцію на Месьє, щоб вбити власну господиню окрім бажання отримати невеликий спадок, ними керує особиста неприязнь, а скоріше занадто складна для їх примітивного розуміння суміш обожнення, захоплення та ненависті. У відсутності господині, яка страждає за чоловіком, вони розігрують між собою сцени вбивства Мадам, вдягнувши їі одяг і пародіюючи пластику та манеру говорити. Вони вирішують отруїти Мадам, додавши у липовий відвар снодійне, щоб імітувати самогубство. Плани сестер руйнує повернення Месьє, якого тимчасово випустили на свободу, i, побоюючись можливого викриття, Клер випиває отруту сама, а Соланж збирається оголосити, що вона її вбила, щоб піти на каторгу. Раціональність і логічність дій у п'єсі замінена логікою почуттів, дією на емоціях та від емоційного стану (Жене, 2001, с.49-84).

Постановка вражала незвичним естетизмом постмодерністського мистецтва: «незвичним було все - від гриму, що нагадував маски театру Кабукі, вбрання Месьє, який поставав у розкішній шубі зі шлейфом дорогих французьких парфумів - до надривного голосу Даліди і головне - особливого способу акторського існування, побудованого на збереженні дистанції між власним образом» (Глэм, 2007). За визначенням критиків, вишукана вистава-ритуал стала основою стилю, що невдовзі став відомий як «стиль Віктюка» - витончені лінії модерну, краса та фантастика театральної дії (Глэм, 2007). 
Р. Віктюк (2003, с.82) згадував, що наприкінці 1980-х років факт наявності на сцені кількох напівоголених чоловіків у жіночих спідницях викликав підвищений інтерес, оскільки був «безглуздям хоробрості, що відкривала заборонені двері, перед цілою гвардією удаваних моралістів».

Унікальність режисерської думки «Служниць» Р. Віктюка не в тому, що чоловіки зображують жінок, а в тому, що їм вдається вловити негативну іпостась людської натури, що більш властива саме жінкам - інтриги та заздрощі. Відповідно до задуму режисера виконання чоловіками жіночих ролей у цьому разі зумовлено прагненням відійти від «кухонних чвар, приватного випадку, зведення рахунків через якогось молочника [...], коли це грають артисти, причому зовсім відчужено, а панівною є естетика Оскара Уайльда: мистецтво визначає життя, естетика не правдоподібності, а вибуху підсвідомості, тоді відкривається філософія Жене» (Виктюк, 2003. с.82).

Того ж таки 1988 року Р. Віктюк здійснив на сцені Театру на Таганці першопрочитання п'єси «Федра» Марини Цвєтаєвої, написаної в 1923-1928 роках. Історію доньки критського царя Міноса, яка зажадала свого пасинка Іпполіта, потім обмовила його, а після загибелі - заподіяла собі смерть, режисер ототожнив з перипетіями життя самої Марини Цвєтаєвої. П'єса була однією з восьми драматичних творів письменниці, об'єднаних у два цикли: «Романтика» - п'єси «Червоний валет», «Заметіль», «Пригоди», «Фортуна», «Кам'яний янгол» та «Фенікс», пов'язані єдиною естетикою, системами персонажів, структурою конфлікту, та незавершена трилогія «Гнів Афродіти», до якої увійшли п'єси «Аріадна», «Федра» та «Єлена», кожна з яких презентує власний жіночий образ, але в конфлікті з єдиним геро$€ м$ - Тезеєм. Ця трагедія вирізняється серед інших п'єс, проте провідною в ній лишається проблематика, характерна для циклу «Романтика» і для всієї творчості М. Цвєтаєвої (Смольяков, 1998, с. 18).

Саме постановка вистави «Федра» за п'єсою М. Цвєтаєвої стала важливим моментом у пошуках принципів поетичного театру.

На думку мистецтвознавця О. Смольякова, театр М. Цвєтаєвої - це передусім емоційний театр, в якому яскраві сильні почуття поєднані не тільки в окремих ситуаціях, а й в усіх складових драматичного тексту (опис дійових осіб, ремарки, особливості образного ряду, специфіка вірша, що диктує власний ритм, настрій і темп розвитку дії). Дослідник припускає, що саме в цьому полягає зв'язок театральної моделі поетеси з театром свого часу, проте це театр не Є. Вахтангова, наприклад, а Камерний театр О. Таїрова, котрий був надзвичайно близький їй духовно й естетично. Крім того, є припущення, що ідея трилогії цвєтаєвської «Гнів Афродіти» виникла під впливом постановок О. Таїрова за античними сюжетами - «ФаміраКіфаред» та «Федра» (Смольяков, 1998, с.17).

Р. Віктюк, провівши паралелі між колізіями долі Федри та Марини Цвєтаєвої, акцентував увагу глядача саме на трагедії поетеси (Гений, страсть и зданиешестеренка, 2019). Головну роль виконала Алла Демидова, а темну та світлу сторони їі душі - Ерос і Танатос - тепле і холодне начало, що боролися в серці та свідомості героїні, втілювали у сміливому пластичному малюнку Дмитро Пєвцов та Олексій Серебряков, між якими режисер умовно розподілив текст Іпполіта та Годувальниці (Шаинян, 2015). 
На думку мистецтвознавців, Р. Віктюк надзвичайно зухвало та точно поставив «Федру» - естетську і водночас безжалісно ясну виставу, в якій актриса А. Демидова наблизилася до масштабів особистості М. Цвєтаєвої (Смольяков, 1998, с.18). Режисер вирішив історію про зраду дружини та її кохання до пасинка, а також наступних страждань і каяття в дусі грецької містерії, репрезентувавши глядачу скоріше не театральну виставу, а священнодію. Показовою та навіть декларативною була спроба поглянути на п'єси М. Цвєтаєвої крізь призму особистості самої поетеси. Для цього режисер поєднав п'єсу М. Цвєтаєвої з уривками з її щоденників та, залишивши центральним образом Федру, спроєктував химерно переломлений міф на долю поетеси - вдалому сценічному втіленню посприяла яскрава індивідуальність Алли Демидової, відточена найвищою акторською майстерністю. О. Смольяков зазначає:

«Серед порожнього простору таганківської сцени на тлі цегляної стіни метушилися Цариця-Жінка-Поету споконвічних стражданняхроздвоєння протиріч буття. Тонка гра з культурними контекстами включала і ледь іронічну імітацію античних скульптур Іпполітом, і чоловіка в ролі Годувальниці, при цьому дивне поєднання оголеного торса та спідниці створювали відчуття архаїки, водночас натякаючи на античний театр, в якому, як відомо, жіночі ролі виконували чоловіки». (Смольяков, 1998, с.17).

«Федра» Р. Віктюка перегукувалася з легендарною постановкою Олександра Таїрова передусім незвичною для 1988 року, підкресленою театральністю рішень режисера, який постійно зміщував часові площини (приміром, звучав вірш Осипа Мандельштама, присвячений Сарі Бернар - ще одній «відомій Федрі»).

Поет Павло Антокольський (1988, с.17-18) акцентує на тому, що М. Цвєтаєва розгледіла архаїчне, первісне ядро - праміф, повернувши жанр трагедії до його елевсінського першоджерела, про який сучасні європейці можуть судити завдяки розкопкам на Криті або уламкам Пергамського фризу.

Йдучи за драматургом, Р. Віктюк створив театр чуттєвий та архаїчно простий шорстка цегляна стіна, чорне важке пальто, оголене тіло та гладке біле трико, що демонстрували позачасову сутність фактури і кольору.

У виконанні Алли Демидової Федра ніби вела діалог з Федрою, яку втілила Аліса Коонен, доводячи, що на сьогодні пристрасті та ситуації, можливо, і змінилися, проте незмінною лишилася гострота і трагічність людського буття. На думку О. Смольякова (1988, с.22), стиль «Федри» Р. Віктюка був спробою створити стиль сучасної трагедії, як колись шукав стиль сучасної трагедії О. Таїров.

Одним з головних художніх засобів у віктюківській «Федрі» стала стилізація - режисер звернувся до «внутрішнього синтезу доби або явища», прочитав п'єсу крізь призму не стільки міфологічних конструкцій, скільки культурологічних. Для нього Федра - передусім один з найцікавіших образів світового театру, з яким пов'язаний тріумф багатьох провідних актрис, оскільки цей образ поєднує велич пристрастей і гостроту ситуацій, граничне напруження існування та глибину вічності.

Театральна критикиня Інга Радова (2018) стверджує, що саме в роботі над постановкою цієї п'єси народилася «химерна віктюківська стилістика, що ста- 
ла фрірмовим знаком його авторського театру, з характерною пластикою, гримом, спорідненим з театром Кабукі, з незвичною вокалізацією, в якій велику роль відіграє звукозапис, вокальні інтонації». На її думку, саме в насиченій інтелектуальній прозі М. Цвєтаєвої, в якій утілено найсерйозніший конфлікт з усіх можливих - між людиною і божеством, з неможливим, забороненим коханням, з трагічною долею художника у світі, режисер віднайшов усе, що є найбільш важливим для нього як для митця.

Перебудова радянського суспільства, зміна політичної системи в другій половині 1980-х років посприяла виникненню нової культурної ситуації. Галина Зайнуліна (2010) акцентує на тому, що після 1985 року, коли політика гласності, розпочата новим радянським керівництвом, несподівано змінила духовне життя людей, народу стали дозволяти критикувати авторитети, а нові закони значно послабили тоталітаризм іоднопартійну систему, в офіційному театральному мистецтві з'явилися елементи соцарту.

Відомий театрознавець Анатолій Смелянський на основі спостереження за тогочасним театральним процесом акцентує на значній кількості вистав, в яких використано прийоми соцарту:

«Перш за все сцена часів перебудови працювала в режимі “зворотних знаків", висміюючи та руйнуючи радянські ігрові маски - революційних вождів, партійних секретарів та передових колгоспників. Невдовзі в справу було введено нові маски - "інтердівчат", злодіїв-кегебешників, героїв-десидентів. Пуританські мовні норми було зруйновано на сцені та на екрані з тією ж легкістю, з якою руйнувалися тілесні табу» (Смелянский, 1999, с. 196).

До вистав з елементами соцарту, представлених у репертуарі театру Р. Віктюка (ще неофіційної антрепризи), дослідники зараховують постановку п'єси «Уроки майстра» Д. Паунелла (1990) на сцені Державного академічного театру імені $€$. Вахтангова (Зайнуллина, 2010, с.4-5).

П'єса належить англійському драматургу, який не беручи за основу історичний матеріал, презентував п'єсу-роздум, що за жанровим спрямуванням нагадує фарс - Сталін (М. Ульянов) та Жданов (О. Філіпенко) вчать великих композиторів Шостаковича (С. Маковецький) та Прокоф'єва (Ю. Яковлєв), як треба писати музику. Весь жах полягає в тому, що композитори з повагою слухають їх, хоча й розуміють абсурдність ситуації. Автор навмисно перевів конфлікт з історичного до загальнолюдського, зробивши персонажів не живими постатями, а умовними масками, цікаво розписавши п'єсу на чотирьох головних виконавців (окрім них єдиним персонажем є секретарка-сержант, роль якої виконала Г. Коновалова).

У чорно-білому порожньому та холодному просторі художника В. Боєра, який зробив яскраво-червоний акцент лише на колах грамплатівок, режисер змоделював власне бачення того, як саме радянські вожді, знущаючись з композиторів, писали власну музику, значно ускладнивши та поглибивши смислотворчі аспекти п'єси. Наприкінці п'єси Сталін, який безроздільно володарював над усіма, раптово осмисливши, що Бог вище його і над Богом він не має влади, божеволіє (Ульянов, 2017). 
Bulletin of Kyiv National University of Culture and Arts

Series in Stage Art

У продовженні думки варто наголосити на тому, що естетика соцарту на вахтанговській сцені стала черговим яскравим елементом загальної палітри режисерських стилістичних уподобань і захоплень Майстра. Протягом своєї творчої кар'єри він апробував найрізноманітніші тематичні й жанрові комбінації, серед яких найбільші враження публіка отримувала саме від експериментів у царині пластичного мистецтва.

Специфіка використання пластичного мистецтва у виставах Р. Віктюка. Осмислення пластичного мистецтва як важливого елемента драматичного театру актуалізувалося на початку XX століття, отримавши значний розвиток у теоретичних працях Андрія Бєлого, Рудольфа Штайнера, В'ячеслава Іванова, Максиміліана Волошина, а головне - у сценічній практиці Всеволода Меєрхольда, Євгена Вахтангова, Михайла Чехова, Олександра Таїрова та ін. Провідні діячі культури і мистецтва, літератори та філософи мріяли про театр, в якому людина буде відчувати істинні, високі почуття під час та після вистав. Так, наприклад, пластика актора та ритмічна організація дії завжди були домінантними компонентами постановок Всеволода Меєрхольда - використовуючи безмежні можливості акторів, які пройшли спеціальну підготовку, він створював у драматичних виставах особливу реальність, що вражала, шокувала, проте жодного глядача не лишала байдужим (Юшкова, 2004, с.11). За Всеволодом Меєрхольдом (1968, с.142), гра актора має бути підкорена «ритму дикції та ритму пластичних рухів», оскільки його творчість - «це творчість пластичних форм у просторі» (Мейерхольд, 1968, с.488).

Подібні ідеї були відновлені в театральному просторі, передусім у режисерських акціях та висловлюваннях, 1970-2000-х років. У цьому контексті Театр Романа Віктюка - це театр, що оповідає не про побутові проблеми, а про життєві універсалії засобами метафор, символів, конфігурацій пластичних малюнків. Творення нової сценічної форми вимагає насамперед від виконавців ролей виразної пластики, мобільності рухів, серйозної фізичної підготовки. Візуальний зміст у постановках режисера - вкрай важливий, він не поступається місцем вербальним засобам виразності актора, а відтак пластична підготовка акторів одна з головних умов прийому на роботу до театру.

Аналізуючи специфіку постановок Театру Романа Віктюка - театру, який не просто розважає глядача, а передусім виражає певні метафізичні ідеї, можемо зазначити, що провідне місце режисер відводить саме пластичному мистецтву.

Деякі театральні критики та мистецтвознавці порівнюють формотворчі експерименти Р. Віктюка зі здобутками Олександра Таїрова, котрий у своїх ранніх пошуках активно працював над пластикою та ритмом вистави, ставив пантоміми і мімодрами, а також синтетичні постановки, в яких провідними засобами виразності були пластичні композиції. Сам О. Таїров називав свої пошуки «театром емоційно насичених форм».

У структурі режисури О. Таїрова, у центрі сценічного дійства перебував актор, який віртуозно володів тілом і не ховався за декораціями або текстом.

Так само й Р. Віктюк у власних театральних пошуках апробував засади пластичного театру. Його режисура повсякчас насичена музикою та різноманітними пластичними ремінісценціями минулих епох або стилів. 
Наприклад, у виставі «Саломея» (1998) за О. Вайльдом Р. Віктюк, між іншим, використовує елементи айкідо (акторам довелося відвідувати заняття із цього виду спорту) (Жаркова, 2008). Так само й у третій редакції вистави «Служниці» (2006) особливу підступність Клер та Соланж актори Олександр Солдаткін і Дмитро Бозін демонструють завдяки пластичному мистецтву - вони повзають на підлозі, наслідуючи змій. У власних театральних пошуках Р. Віктюк впритул наближається до пластичного театру. Режисура та світовідчуття Р. Віктюка повсякчас насичене музикою та власними уявленнями про пластику. Відтак режисер разом з апологетикою пластичної режисури, захоплюючись елементами експресіонізму та авангарду, активно використовує й символи та підтекстове начало літературних першоджерел.

Концептуальною роль руху стала у виставі Театру Романа Віктюка «Лоліта» (1992) - відповідно до задуму головного режисера та режисера з пластики В. Гнеушева саме пластична виразність акторів дає можливість «повертатися до минулого, зазирати в майбутнє, показувати географію душі» (Кретова, 1992). Валентин Гнеушев - відомий цирковий режисер, який наситив постановку Р. Віктюка цирковою естетикою, що увиразнилася в пластичних малюнках образу Лоліти (Ірина Метлицька практично не опускалася на сцену, рухаючись величезною металевою трикутною конструкцією, демонструючи, на думку критиків, істинну акробатичну майстерність) (Кретова, 1992) та всіма чоловічими персонажами у виконанні Сергія Маковецького (Куінсі), Сергія Виноградова (Невідомий джентльмен) та Олега Ісаєва (Гумберт Гумберт) - їх танець вирішено у стилістиці чоловічого кабаре.

На думку Інги Радової (2018), у поетиці Театру Романа Віктюка пластика, музика та слова мають рівні права. Закоханість режисера в естетику модерну з його витонченими лініями, вигинами, зламами передається і пластиці: «через мову тіла, виразну міміку зі сцени транслюється і схвильована емоційність, і нервовість почуттів, що спокушає, і тонкий психологізм».

Відповідно до особливої поетики та високого ступеня театральності, характерних антипобутовому, синтетичному та неканонічному Театру Романа Віктюка, його провідні актори (Д. Бозін, О. Ісаєв, Л. Погорєлова, О. Дзюба та ін.) володіють неповторною органікою, надзвичайною пластичною виразністю, майстерним володінням тілом, унікальним, гіпнотичним стилем руху.

Однією з найбільш близьких Р. Віктюку концепцій щодо пластики в режисерському мистецтві є концепція, викладена американським драматургом Теннесі Вільямсом у «Замітках до постановки» п'єси «Скляний звіринець».

Письменник зауважує, що замітки не просто передмова до п'єси, оскільки в них закладена концепція нового пластичного театру, котрий має замінити вичерпані засоби зовнішньої правдоподібності, в прагненні, щоб «театр, як частина нашої культури, знову отримав життєподібність» (Уильямс, 2007, с.7). Відповідно до цієї концепції, у театральній постановці режисер має використовувати всі театрально-сценічні прийоми, включно з екраном, музикою, освітленням, безпосередньо пластичними жестами та розташуванням акторів на сцені, символізмом декорацій і поведінкою персонажів. Використовуючи ці засоби, Т. Вільямс 
Bulletin of Kyiv National University of Culture and Arts

Series in Stage Art

з успіхом вирішує завдання висвітлення певного психологічного стану, настрою, а також сценічно виражає власну думку.

На думку Р. Віктюка, у концепції Т. Вільямса простежується сутність усієї творчості великого американського драматурга, відтак надзвичайно важливим є розуміти та використовувати її в процесі здійснення постановок його творів. Р. Віктюк зазначає:

«Скільки було постановок п'єс Вільямса, проте, як на мене, більшість з них не передавали тієї своєрідності, якою наділений цей чудовий майстер. Чому? Причин, як на мене, кілька... Звертаючись до Вільямса, ми, люди мистецтва, чомусь зазвичай забуваємо про викладену драматургом в передмові до відомого "Скляного звіринця" концепцію “пластичного театру" [...] Де яскраві кольори, гра світла, виразні жести, сценічний рух, пластика персонажів, музика, танці? Де химерні символи? Де, зрештою, герої "не від світу цього"? Адже з усього цього складається неповторна атмосфера вільямсівських п'єс». (Виктюк, 1993, с.5-6)

Режисер Р. Віктюк звертався до творчості Т. Вільямса лише двічі - після «Татуйованої троянди» 1982 року (вистава залишалася в репертуарі МХАТу ім. Максима Горького протягом 26 років) він здійснив постановку, музичне оформлення та сценічну адаптацію п'єси «І раптом минулого літа» (2016) про трагічну долю поета Себастьяна Вінебла та роль мистецтва в житті творчої людини.

За сюжетом, головна героїня - Місис Вінебл (Л. Погорєлова) - втратила єдиного сина Себастьяна, який був для неї коханням і сенсом життя. Вона прагне приховати моторошні та непристойні обставини його смерті (поета роздерли нелюди-туземці на мексиканському курорті), проте Кетрін (Є. Карпушина), родичка, яка супроводжувала Себастьяна, постійно нагадує про них у мареннях. Місис Вінебл наполягає, щоб дівчині зробили лоботомію, запрошуючи доктора Цукровича (М. Половенко); водночас матір (М. Казначеєва) та брат (Н. Косточко) Кетрін також вмовляють її піти на операцію, оскільки зацікавлені отримати спадок.

Відмовившись від сценічних ефектів, режисер розкрив сенс вистави крізь постійні бійки, метушню та жерстяний гуркіт невеликої круглої сцени - світ без поета гидкий, а життя затухає, розчавлене нелюдською жорстокістю.

Режисерському баченню відповідає і сценографічне рішення: у глибині сцени (простір-трансформер, що оздоблено найновішою світловою апаратурою) круглого помосту, котрий оббито залізом та обвішано ланцюгами, знаходиться портал у вигляді величезної людської потилиці з об'ємним вухом, що поростає гіллям; ліворуч - білий рояль, на першому плані - велосипеди, лавка, жерстяні табурети й інвалідний візок; на сцені розкидано іржаві залізні троянди, зігнуті велосипеди та покручені велосипедні колеса - знак викривленого простору та часу, руху зламаного життя, що зупинилося, зруйнованої досконалості ідеальної геометричної форми. Розповідаючи історію про поета, режисер ніби цитує елементи власних вистав (Шаинян, 2016), до того ж у вступній ремарці Т. Вільямс акцентував, що оформлення вистави може, якщо не повинно, мати «сюрреалістичний» характер. Молитовні лавки в оксамитовій оббивці розміщено по сусідству з лавками металевими, і залізний гуркіт постійно перекриває людські голоси. 
На думку Р. Віктюка, кохання - це єдина заповідь існування людини. Вистава «l раптом минулого літа» якраз про втрату кохання, про біль і безвихідь. Утім, якщо розглянути величезний режисерський доробок Майстра, то неозброєним оком видно, що більшість його робіт саме про кохання в найрізноманітніших проявах, а також про таємниці життя, неможливість осягнення буття та людську самотність.

\section{Висновки}

Найбільш резонансні вистави Р. Віктюка великою мірою шокували глядача виконанням чоловіками жіночих ролей, відвертим пропагуванням одностатевого кохання та, здавалося б, порушенням законів загальноприйнятої моралі. Ці бунтарські творчі маніфести підкреслювали специфіку режисури Р. Віктюка. Утім, вирізняючись від звичних театральних постановок розмаїттям музики та хореографії, вишуканою пластикою напівоголених виконавців, яскравими костюмами та сценами епатажу, режисерські меседжі Р. Віктюка фокусувалися на складних філософських питаннях, увиразнювали новаторський погляд на природу людських стосунків, переосмислення літературних творів. У виставах, здійснених у межах психологічного, метафоричного й пластичного театру, продемонстровано жанрову та стилістичну поліфонію режисури Р. Віктюка.

Власне, наукова новизна цієї статті визначається введенням до вітчизняного наукового обігу фрагментів театральної режисури Р. Віктюка, полягає в окресленні жанрово-стилістичних особливостей його постановок, розгляді епізодів найбільш резонансних вистав. Адже вплив режисури Р. Віктюка, у тому числі й на експериментальні процеси українського театру межі 1980-1990-х років, переоцінити важко. Цей факт спонукає до подальших теоретичних узагальнень сценічного доробку Майстра, оскільки поточна стаття лише накреслює можливі орієнтири для майбутніх досліджень.

\section{СПИСОК ПОСИЛАНЬ}

Агишева, Н., 1988. Звуки «Му»: о драматургии Л. Петрушевской. Театр, 9, с.55-64.

Антокольский, П., 1988. Вступительная статья. В: Эфрон, А. Саакянц А. сост., Театр. Москва: Искусство, с.5-22.

Верховець, Н., 1989. Рятуймо наші душі! Радянська Україна, 22 жовтня.

Виктюк, Р. и Печегина, Т., 2018. Небо. Полет второй. Москва: Зебра Е.

Виктюк, Р. и Печегина, Т., 2018. Небо. Полет первый. Москва: Зебра Е.

Виктюк, Р., 1993. Фиалки - к свету, розы - к жизни. В: Уильямс, Т. Желание и чернокожий массажист. Москва: Прогресс, с.5-6.

Виктюк, Р., 2003. Роман с самим с собой. Москва: Зебра Е.

Гений, страсть и здание-шестеренка. Как устроен театр Романа Виктюка, 2019. [online] 30 апреля. Доступно: <https://www.mos.ru/news/item/54845073/> [Дата обращения 05 октября 2020].

Глэм, Т., 2007. Не возвращайтесь к былым возлюбленным. [online] Доступно: <http://samlib. ru/t/tatxjana_g/slujanki-3.shtml> [Дата обращения 10 сентября 2020]. 
Гринишина, М., 2017. Національний академічний театр російської драми ім. Лесі Українки (1926-2014рр.). В: Гринишина, М. ред. Нариси з історії інонаціонального театру в Україні XX-початку XXI ст. Київ: Фенікс, с.141-335.

Жаркова, Е., 2008. Театр Виктюка разговаривает с Богом. [online] 18 декабря. Доступно: <http://www.vremyan.ru/interviews/teatr_viktjuka_razgovarivaet_s_bogom_.html> [Дата обращения 05 октября 2020].

Жене, Ж., 2001. Служанки. Перевод: А. Миролюбовой. В: Театр Жана Жене: Пьесы, статьи, письма. Санкт-Петербург: Гуманитарная Академия, с.49-84.

Зайнуллина, Г.И., 2010. Элементы соц-арта и постсоц-арта в татарском драматическом театре на рубеже XX-XXI веков. Автореферат дисертаций кандидата искусствоведения. Российская академия театрального искусства.

Иванов, А.П., 2012. Субкультура недавнего прошлого. Дружба Народов, [online] 6. Доступно:<https://magazines.gorky.media/druzhba/2012/6/subkultury-nedavnego-proshlogo. html> [Дата обращения 10 сентября 2020].

Каблукова, Н.В., 2003. Поэтика драматурги Людмилы Петрушевской. Благовещенск: Благовещенский государственный педагогический университет.

Кретова, Е., 1992. "Лолита": о любви без эротики. Премьера в театре Романа Виктюка. Коммерсанть, 25.

Курпатов, А., 2018. Страх. Сладострастие. Смерть. Москва: Litres.

Липківська, А.К., 2012. Ж. Кокто «Священні чудовиська» В: Гринишина, М. ред., Український театр XX ст.: Антологія вистав. Київ: Фенікс, с.793-806.

Литвин, Б.М., 1993. Поиск образности в творчестве режиссера. Автореферат дисертации кандидата искусствоведения. Российский институт искусствознания.

Мейерхольд, Вс.Э., 1968. Статьи, письма, речи, беседы. Москва: Искусство. Ч. 2.

Мирошниченко, И.П., 2017. Расскажу... Москва: АСТ. [online] Доступно: <https://kartaslov.ru/ книги/Мирошниченко_И_П_Расскажу/3> [Дата обращения 10 сентября 2020].

Мурзич, А., 2008. Театр Романа Виктюка. Из точки в вечность. Санкт-Петербург: Знание. Николаев, Г., 2014. Ожидание свободы. Санкт-Петербург: Звезда.

Петрушевская, Л., 2006. Маленькая девочка из «Метрополя» Санкт-Петербург: Амфора.

Радова, И., 2018. Роман Виктюк: искусство быть свободным. Кругозор. [online] Доступно: <https://www.krugozormagazine.com/show/roman-viktyuk.3632.html> [Дата обращения 10 сентября 2020].

Романова, Е.В., 2004. Театр в эстетико-семиотическом дискурсе: на примере отечественной и западноевропейской театральной практики второй половины XX века. Автореферат дисертации кандидата философских наук. Московский государственный университет имени М. В. Ломоносова.

Смелянский, А.М., 1999. Предполагаемые обстоятельства: Из жизни русского театра второй половины XX века. Москва: Артист. Режиссер. Театр.

Смольяков, А.Ю., 1998. Стилизация в русской поэтической драме начала XX века: драматургический цикл М.И. Цветаевой «Романтика». Кандидат искусствоведения. Российская Академия театрального искусства.

Спиридонова, А., 1989. Уроки дає майстерність. Культура і життя, 25 липня.

Уильямс, Т., 2007. Орфей спускается в ад. Санкт-Петербург: Азбука-классика.

Ульянов, М., 2017. Приворотное зелье. Москва: Алгоритм. 
Шаинян, Н., 2015. Чистые эссенции страстей. Театрал, 25 июля.

Шаинян, Н., 2016. В театре Романа Виктюка поставили Теннесси Уильямса. Российская газета. [online] Доступно: <https://rg.ru/2016/10/31/pervoj-premeroj-v-teatre-viktiuka-stalapesa-i-vdrug-minuvshim-letom.html> [Дата обращения 05 октября 2020].

Юшкова, Е.В., 2004. Пластический театр в России XX века. Автореферат дисертации кандидата искусствоведения. Ярославский государственный педагогический универсисте им. К.Д. Ушинского.

\section{REFERENCES}

Agisheva, N., 1988. Zvuki "Mu": o dramaturgii L. Petrushevskoj [Sounds of "Mu": about the drama of L. Petrushevskaya]. Teatr, 9, pp.55-64.

Antokolskij, P., 1988. Vstupitelnaja statja [Introductory article]. In: Jefron, A. Saakjanc, A. comp. Teatr [Theater]. Moscow: Iskusstvo, pp.5-22.

Genii, strast i zdanie-shesterenka. Kak ustroen teatr Romana Viktiuka [Genius, passion and gear building. How Roman Viktyuks theater works], 2019. [online] 30 April. Available at: <https:// www.mos.ru/news/item/54845073/> [Accessed 05 September 2020].

Gljem, T., 2007. Ne vozvrashhajtes $k$ bylym vozljublennym [Dont Return to Your Past Lovers]. [online] Available at: <http://samlib.ru/t/tatxjana_g/slujanki-3.shtml> [Accessed 10 September 2020].

Hrynyshyna, M., 2017. Natsionalnyi akademichnyi teatr rosiiskoi dramy im. Lesi Ukrainky (19262014 rr.) [National Academic Theater of Russian Drama. Lesya Ukrainka (1926-2014)]. In: Hrynyshyna, M. ed. Narysy z istorii inonatsionalnoho teatru v Ukraini XX-pochatku XXI st. [Essays on the history of non-national theater in Ukraine in the XX-early XXI century]. Kyiv: Feniks, pp.141-335. Ivanov, A.P., 2012. Subkultura nedavnego proshlogo [Subculture of the recent past]. Druzhba Narodov, [online] 6. Available at: <https://magazines.gorky.media/druzhba/2012/6/subkulturynedavnego-proshlogo.html> [Accessed 10 September 2020].

Jushkova, E.V., 2004. Plasticheskij teatr $v$ Rossii XX veka [Plastic theater in Russia of the $X X$ century]. Abstract of the dissertation of the candidate of art history. Jaroslavskij gosudarstvennyj pedagogicheskij universiste im. K.D. Ushinskogo.

Kablukova, N.V., 2003. Pojetika dramaturgi Ljudmily Petrushevskoj [Poetics of the playwright Lyudmila Petrushevskaya]. Blagoveshchensk: Blagoveshhenskij gosudarstvennyj pedagogicheskij universitet.

Kretova, E., 1992. "Lolita": o ljubvi bez jerotiki. Premera v teatre Romana Viktjuka ["Lolita": about love without eroticism. Premiere at the Roman Viktyuk Theater]. Kommersant, 25.

Kurpatov, A., 2018. Strah. Sladostrastie. Smert [Fear. Voluptuousness. Death]. Moscow: Litres. Litvin, B.M., 1993. Poisk obraznosti $v$ tvorchestve rezhissera [Search for imagery in the directors work]. Abstract of the dissertation of the candidate of art history. Rossijskij institut iskusstvoznanija.

Lypkivska, A.K., 2012. Zh. Kokto "Sviashchenni chudovyska" [J. Kokto "Sacred Monsters"] In: Hrynyshyna, M. ed., Ukrainskyi teatr XX st.: Antolohiia vystav [Ukrainian Theater of the XX century: Anthology of performances]. Kyiv: Feniks, pp.793-806.

Mejerhold, Vs.Je., 1968. Stati, pisma, rechi, besedy [Articles, letters, speeches, conversations]. Moscow: Iskusstvo. Ch. 2. 
Miroshnichenko, I.P., 2017. Rasskazhu... [IIl tell you ...]. Moscow: AST. [online] Available at: <https://kartaslov.ru/knigi/Miroshnichenko_I_P_Rasskazhu/3> [Accessed 10 September 2020]. Murzich, A., 2008. Teatr Romana Viktjuka. Iz tochki v vechnost [Roman Viktyuk Theater. From a point to eternity]. St. Petersburg: Znanie.

Nikolaev, G., 2014. Ozhidanie svobody [Expectation of freedom]. St. Petersburg: Zvezda.

Petrushevskaja, L., 2006. Malenkaja devochka iz "Metropolja" [Little girl from "Metropol"] St. Petersburg: Amfora.

Radova, I., 2018. Roman Viktjuk: iskusstvo byt svobodnym [Roman Viktyuk: the art of being free]. Krugozor. [online] Available at: <https://www.krugozormagazine.com/show/romanviktyuk.3632.html> [Accessed 10 September 2020].

Romanova, E.V., 2004. Teatr v jestetiko-semioticheskom diskurse : na primere otechestvennoj i zapadnoevropejskoj teatralnoj praktiki vtoroj poloviny XX veka [Theater in aesthetic and semiotic discourse: on the example of Russian and Western European theater practice in the second half of the twentieth century]. Abstract of the dissertation of the candidate of philosophical sciences. Moskovskij gosudarstvennyj universitet imeni M. V. Lomonosova.

Shainjan, N., 2015. Chistye jessencii strastej [Pure essences of passions]. Teatral, 25 July.

Shainjan, N., 2016. V teatre Romana Viktjuka postavili Tennessi Uiljamsa [Tennessee Williams was staged at the Roman Viktyuk Theater] Rossijskaja gazeta. [online] Available at: <https:// rg.ru/2016/10/31/pervoj-premeroj-v-teatre-viktiuka-stala-pesa-i-vdrug-minuvshim-letom. html> [Accessed 05 September 2020].

Smeljanskij, A.M., 1999. Predpolagaemye obstojatelstva: Iz zhizni russkogo teatra vtoroj poloviny $X X$ veka [Alleged circumstances: From the life of Russian theater in the second half of the XX century]. Moscow: Artist. Rezhisser. Teatr.

Smoljakov, A.Ju., 1998. Stilizacija $v$ russkoj pojeticheskoj drame nachala $H H$ veka: dramaturgicheskij cikl M.I. Cvetaevoj "Romantika" [Stylization in Russian poetic drama of the early twentieth century: the dramatic cycle of M.I. Tsvetaeva "Romance"]. Ph.D. in History of Arts. Rossijskaja Akademija teatralnogo iskusstva.

Spyrydonova, A., 1989. Uroky daie maisternist [Lessons are given by skill]. Kultura i zhyttia, 25 July. Uiljams, T., 2007. Orfej spuskaetsja v ad [Orpheus Descends to Hell]. St. Petersburg: Azbukaklassika.

Uljanov, M., 2017. Privorotnoe zele [Love potion]. Moscow: Algoritm.

Verkhovets, N., 1989. Riatuimo nashi dushi! [Lets save our souls!] Radianska Ukraina, 22 October.

Viktjuk, R. and Pechegina, T., 2018. Nebo. Polet pervyj [Sky. First flight]. Moscow: Zebra E.

Viktjuk, R. and Pechegina, T., 2018. Nebo. Polet vtoroj [Sky. Second flight]. Moscow: Zebra E.

Viktjuk, R., 1993. Fialki - k svetu, rozy - k zhizni. In: Uiljams, T. Zhelanie i chernokozhij massazhist [Violets - to the light, roses - to life]. In: Williams, T. Desire and the Black Masseur. Moscow: Progress, pp.5-6.

Viktjuk, R., 2003. Roman s samim s soboj [An affair with himself]. Moscow: Zebra E.

Zajnullina, G.I., 2010. Jelementy soc-arta i postsoc-arta $v$ tatarskom dramaticheskom teatre na rubezhe $X X-X X I$ vekov [Elements of Sots Art and Post-Sots Art in the Tatar Drama Theater at the turn of the $X X-X X I$ centuries]. Abstract of dissertations of the candidate of art history. Rossijskaja akademija teatralnogo iskusstva. 
Zharkova, E., 2008. Teatr Viktjuka razgovarivaet s Bogom [Viktyuk Theater talks to God]. [online] 18 December. Available at: <http://www.vremyan.ru/interviews/teatr_viktjuka_razgovarivaet_s_ bogom_.html> [Accessed 05 September 2020].

Zhene, Zh., 2001. Sluzhanki [Servants]. In: Teatr Zhana Zhene: Pesy, stati, pisma [Theater Jean Genet: Plays, articles, letters]. Translation: A. Mirolyubova. St. Petersburg: Gumanitarnaja Akademija, pp.49-84.

\title{
ЖАНРОВО-СТИЛИСТИЧЕСКАЯ ПОЛИФОНИЯ РЕЖИССЕРСКОГО ТВОРЧЕСТВА РОМАНА ВИКТЮКА
}

\author{
Татьяна Бойко1a ${ }^{1}$ Ярослав Ланчак²a \\ ${ }^{1}$ кандидат искусствоведения, старший научный сотрудник; \\ e-mail: tetiana.boyko@gmail.com; ORCID: 0000-0001-6941-8868 \\ ${ }^{2}$ магистр; e-mail: lanchak0804@gmail.com; ORCID: 0000-0001-9282-8988

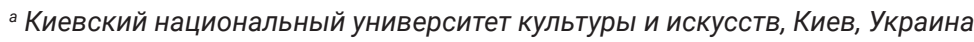

\section{Аннотация}

Цель исследования - выяснить специфику сценического наследия Романа Виктюка, проанализировать отдельные аспекты апробированной пластической режиссуры, определить жанрово-стилистические параметры резонансных постановок мастера конца 1970-х - начала 2010-х гг. на примере спектаклей «Татуированная роза» Т. Уильямса (1982), «Украденное счастье» И. Франко (1982), «Федра» М. Цветаевой (1988), «Священные чудовища» Ж. Кокто (1987), «Уроки музыки» $(1979,1989)$ и «Квартира Коломбины» (1986) Л. Петрушевской, «Уроки мастера» Д. Паунелла (1990), «Служанки» Ж. Жене (1988), «Лолита» Э. Олби (1992), «И вдруг минувшим летом» Т. Уильямса (2016) и др. Методология исследования. Для достижения поставленной цели были использованы общенаучные методы: аналитический (для понимания процесса творческого становления и формирования концептуальных ориентиров режиссера), структурно-типологический (для изучения элементов режиссерского инструментария и художественных приемов мастера), феноменологический (для определения черт оригинальности и эпатажности сценической практики Романа Виктюка). Научная новизна данной статьи определяется введением в отечественный научный контекст фрагментов театральной режиссуры Романа Виктюка, заключается в описании жанрово-стилистических особенностей его постановок, рассмотрении отдельных спектаклей. Выводы. Сценические работы Романа Виктюка отличаются разнообразием музыки и хореографии, изысканной пластикой полуобнаженных исполнителей, яркими костюмами и сценами эпатажа. В то же время режиссерские поиски нацелены на решение сложных философских вопросов, демонстрирующих новый взгляд на природу человеческих отношений, глубинное исследование и переосмысление литературных произведений.

Ключевые слова: пластическое мастерство актера; пластический рисунок роли; художественный образ 


\title{
GENRE-STYLISTIC POLYPHONY OF THE DIRECTOR'S WORK OF ROMAN VIKTYUK
}

\author{
Tetiana Boiko ${ }^{1 a}$, Yaroslav Lanchak ${ }^{2 a}$ \\ ${ }^{1}$ Ph.D. in Art History, Senior Researcher; \\ e-mail: tetiana.boyko@gmail.com; ORCID: 0000-0001-6941-8868 \\ ${ }^{2}$ Master; e-mail: lanchak0804@gmail.com; ORCID: 0000-0001-9282-8988 \\ ${ }^{a}$ Kyiv National University of Culture and Arts, Kyiv, Ukraine
}

\begin{abstract}
The purpose of the research is to find out the specifics of Roman Viktyuk's stage work, to analyze some aspects of the tested plastic directing, to outline genre-stylistic parameters of resonant productions of the artist of late 1970s - early 2010s on the example of T. Williams' "Tattooed rose" (1982), "Stolen Happiness" by I. Franko (1982), "Phaedra" by M. Tsvetaeva (1988), "Sacred Monsters" by J. Cocteau (1987), "Music Lessons" (1979, 1989) and "Columbine's Apartment" (1986) by L. Petrushevskaya, "Master's Lessons" by D. Paunella (1990), "Maids" by J. Genet (1988), "Lolita" by E. Albee (1992), "Suddenly Last Summer" by T. Williams (2016), etc. Research methodology. To achieve this goal, general scientific methods were used: analytical is (to understand the process of creative formation and formation of director's conceptual guidelines), typological and structural are (to study the elements of directing tools and artistic techniques of the artist), and phenomenological is (to determine the originality and outrageousness of stage practice by Roman Viktyuk). The scientific novelty of this article is determined by the introduction into the domestic scientific circulation of fragments of theatrical directing by Roman Viktyuk, consists in outlining the genre and stylistic features of his productions, consideration of individual performances. Conclusions. Roman Viktyuk's stage work is distinguished by a variety of music and choreography, exquisite sculptures of half-naked performers, eloquent costumes and outrageous scenes. At the same time, the director's research is aimed at solving complex philosophical questions that demonstrate a new view of the nature of human relations, in-depth research and rethinking of literary works.
\end{abstract}

Keywords: Roman Viktyuk; author's direction; genre; metaphorical theater; poetic theater; plastic directing; outrage 